\title{
Gamma Globulin
}

National Cancer Institute

\section{Source}

National Cancer Institute. Gamma Globulin. NCI Thesaurus. Code C16601.

A type of globulin in plasma that in electrically charged solutions exhibits slowest colloidal

mobility after that of the alpha and beta globulins. All immunoglobulins belong to this group of serum protein. 